\title{
Carcass characteristics, chemical composition and fatty acid profile of longissimus muscle of young bulls from four genetic groups finished in feedlot
}

\author{
Roberto Haruyoshi Ito ${ }^{1}$, Ivanor Nunes do Prado ${ }^{1^{*}}$, Polyana Pizzi Rotta ${ }^{1}$, Marival Gustavo de \\ Oliveira $^{1}$, Rodolpho Martin do Prado ${ }^{1}$, José Luiz Moletta ${ }^{2}$
}

\footnotetext{
${ }^{1}$ Departamento de Zootecnia, Universidade Estadual de Maringá.

2 Instituto Agronômico do Paraná - IAPAR, Curitiba, Paraná, Brazil.

* Pesquisador $1 A$ do CNPq.
}

\begin{abstract}
This experiment was carried out to evaluate the carcass characteristics, chemical composition and fatty acid profile of the longissimus muscle of 32 young bulls from four genetic groups: Caracu; Canchin; Aberdeen Angus $\times$ Canchin; and Charolais $\times$ Caracu, finished in feedlot and slaughtered at 22 months old. Each group was composed of eight animals. There was no difference for moisture, ash, crude protein or total cholesterol between bulls from different genetic groups. However, total lipids percentage was higher for bulls from Caracu and Aberdeen Angus $\times$ Canchin and lower for Canchin and Charolais genetic groups. Polyunsaturated fattty acids and n-6 percentage was higher for Canchin and lower for Caracu, Aberdeen Angus $\times$ Canchin and Charolais genetic groups. Canchin and Charolais $\times$ Caracu genetic groups presented higher $n-3$ percentage than Caracu and Aberdeen Angus $\times$ Canchin. There was no difference for the $n-6 / n-3$ ratio among the bulls from the four genetic groups.
\end{abstract}

Key Words: Canchin, Caracu, total cholesterol, total lipids

\section{Introduction}

The bovine carcass features have acquired more importance on the national scenery, mainly in function of the exportation increase and the international market growing requirements. Import markets require uniform carcasses with high weight and high quality. However, the genetic group to practice feedlot becomes more important, since there are striking differences between the different carcasses of genetic groups (Ducatti et al., 2009).

Cattle breed is one of the most important factors for fat deposition and composition (Prado et al., 2009a), which needs to be understood because of its genetic transmission. Nevertheless, the detailed mechanisms of this variation and whether or how they can be manipulated are not clearly known. British cattle are known for their highlymarbled meat, while the Zebu breeds contain less fat and more connective tissue (Moreira et al., 2003; Rotta et al., 2009a).

Genetic variability consists of differences between species, breeds or lines; differences due to crossing of breeds; and difference between animals within breeds (Rotta et al., 2009b).The latter source of variation is estimated by heritability and genetic correlations. Breed effects may be influenced by the segregation of major genes; one of which is the double-muscled gene in cattle. It is sometimes difficult to assess the real contribution of genetics to differences in meat quality. Breed comparisons are often confounded by other effects such as fat level, live weight, age at slaughter and production system (Webb, 2006; Rotta et al., 2009b).

The fatty acid profile of the meat is very important for two main reasons: it determines nutritional value and affects various aspects of meat quality, including shelf life and flavor (Wood et al., 2003). Nutritional value is determined in part by the ratio between saturated fatty acids and polyunsaturated fatty acids in meat, as well as the balance between fatty acids of the $n-6$ and $n-3$ series. In general, a polyunsaturated fatty acids-to-saturated fatty acids ratio above 0.45 and a ratio of $n-6 / n-3$ below 4.0 are required in the diet in order to combat various "lifestyle diseases", such as coronary heart disease and cancers (HMSO, 1994).

This study was carried out to evaluate the carcass characteristics, chemical composition and fatty acid profile on longissimus muscle of young bulls from four different genetic groups finished in feedlot and slaughtered at 22 months old. 


\section{Material and Methods}

The committee of Animal Production at the Universidade Estadual de Maringá approved this study (CIOMS, 1985), which was carried out at the Estação Experimental of Instituto Agronômico do Paraná-IAPAR, in the city of Ponta Grossa, Paraná, Brazil.

Thirty-two bulls from four different genetic groups, slaughtered at 22 months of age were used. The experimental design used was randomized, distributed according to the following groups: $\mathrm{Caracu}$; Canchin; Aberdeen Angus $\times$ Canchin; and Charolais $\times$ Caracu, with eight replications each one.

The bulls were weaned at 90 days of age and remained in Hermartria (Hermarthria altissima) pastures grown with supplementation based on $1.5 \mathrm{~kg} / \mathrm{animal} /$ day of the mixture $25 \%$ of soybean meal $+73 \%$ of corn grain $+2 \%$ of mineral salt. After, during the 6 months (spring and summer) bulls remained on Hermartria pastures without supplementation. Bulls were kept in feedlot during 90 days in individual covered stalls, with area of $8 \mathrm{~m}^{2}$, provided with concrete floor, feeder for bulky food, concentrate, and mineral salt and water regulated by a system of automatic ball.

The animals were weighed at the beginning of the experiment at 8:00h. After the initial weighing, periodic weights were done at every 28 days, according to fasting of solids for 16 hours, obtained by the total withdrawal of the feed on the previous day at 16:00h.

The animals received a diet with $12 \%$ of crude protein and $72 \%$ of total digestible nutrients. The forage provided was corn silage and concentrate (composed of $25 \%$ of soybean meal, $73 \%$ of corn grain and $2 \%$ of mineral salt). The roughage:concentrate ratio was 52:48. The formulation of trial and quantity supplied were to provide a weight gain of $1.2 \mathrm{~kg} / \mathrm{day}$, according to the NRC (1996) recommendation (Table 1).

Animals were slaughtered at a commercial slaughterhouse 90 km away from the Ponta Grossa Research Farm, according to industrial practices in Brazil. Following slaughter, carcasses were identified and chilled for $24 \mathrm{~h}$ at $4{ }^{\circ} \mathrm{C}$. After chilling, the right part of the carcass was used to determine the quantitative characteristics. Twenty-four hours later,

Table 1 - Chemical composition of experimental diets (\%DM)

\begin{tabular}{lcc}
\hline Parameters & \multicolumn{2}{c}{ Feed, \% DM } \\
\cline { 2 - 3 } & Concentrate & Corn silage \\
\hline Dry matter (DM) & 87.5 & 32.3 \\
Crude protein & 18.7 & 6.16 \\
Ether extract & 7.0 & 3.05 \\
Ash & 3.10 & 4.60 \\
Neutral detergent fiber & 19.5 & 58.5 \\
Acid detergent fiber & 6.69 & 27.6 \\
\hline
\end{tabular}

longissimus muscle samples were taken by a complete cross section between the $12^{\text {th }}$ and $13^{\text {th }}$ ribs. Fat thickness was discarded and the muscle portion was frozen at $20^{\circ} \mathrm{C}$ for further analyses.

Hot carcass weight: Determined before chilling.

Hot carcass dressing: The percentage of individual animal dressing was defined by the ratio of hot carcass weight and live weight.

Carcass conformation: Evaluated by Müller's (1980) point scale in which the highest value indicates the best conformation; muscle development was considered after the exclusion of fat thickness. The carcass conformation is reported as superior, very good, good, regular, poor, and inferior; ratings may also be reported as plus, average, and minus. Carcass length was evaluated by measurements taken from the skull board to the pubic bone on the anterior side of the first rib.

Fat thickness: It was taken by a caliper averaging three points between the $12^{\text {th }}$ and $13^{\text {th }}$ ribs but over the longissimus muscle.

Longissimus muscle area: The right part of the carcass was measured after a cross-section cut was made between the $12^{\text {th }}$ and $13^{\text {th }}$ ribs using a compensating planimeter, which measures the areas of objects with irregular shapes.

Color: Muscle color after 24-hour carcass cooling was analyzed. Coloration was evaluated according to a point scale 30 min after a cross-sectional cut was made on the longissimus between the $12^{\text {th }}$ and $13^{\text {th }}$ ribs (Müller, 1980).

Marbling: It was measured in the longissimus muscle between the $12^{\text {th }}$ and $13^{\text {th }}$ ribs, following the scores described by Müller(1980).

Percentage of carcass muscle, fat and bone: Muscle, fat and bone were physically separated from the longissimus section, which corresponds to the $10^{\text {th }}, 11^{\text {th }}$ and $12^{\text {th }}$ ribs, and individually weighed according to Hankins \& Howe (1946). Data were regressed to equations by Müller (1973) - the model converts data into values corresponding to the $9^{\text {th }}, 10^{\text {th }}$, and $11^{\text {th }}$ ribs as follows:

$\%$ Muscle $=6.292+0.910 \mathrm{X}_{1}$

$\%$ Fat $=1.526+0.913 \mathrm{X}_{2}$

$\%$ Bone $=2.117+0.860 \mathrm{X}_{3}$

in which: $\mathrm{X}_{1}, \mathrm{X}_{2}$ and $\mathrm{X}_{3}$ represent muscle, fat and bone percentages.

The values corresponding to the $9^{\text {th }}, 10^{\text {th }}$ and $11^{\text {th }}$ ribs were regressed to equations following the methods of Hankins \& Howe (1946) to find the muscle (MP), bone (BP), and fat (FP) percentages.

$\mathrm{MP}=15.56+0.81 \mathrm{M}$;

$\mathrm{FP}=3.06+0.82 \mathrm{~F}$

$\mathrm{BP}=4.30+0.61 \mathrm{~B}$. 
in which $\mathrm{M}, \mathrm{F}$ and $\mathrm{B}$ are the muscle, fat and bone estimates from the equations by Müller et al. (1973).

After 24 hours, longissimus muscle samples were taken by complete cross-section between the $12^{\text {th }}$ and $13^{\text {th }}$ ribs, and were immediately taken to the laboratory. Cover fat was discarded and the muscle portion was frozen at $-20{ }^{\circ} \mathrm{C}$ for later analysis.

Laboratory analyses of beef were carried out two months after sampling. Samples were thawed at room temperature $\left(20^{\circ} \mathrm{C}\right)$, ground, homogenized, and analyzed in triplicate.

Beef moisture and ash contents were determined according to AOAC (1998). Crude protein content was obtained through the Kjeldahl method (AOAC, 1998). Total lipids were extracted through the Bligh \& Dyer (1959) method with a chloroform/methanol mixture. Fatty acid methyl esters were prepared by triacylglycerol methylation, according to the ISO method (1978).

Cholesterol analysis was carried out by the method modified by Rowe (1999). A 60\% (w/v) solution of potassium hydroxide was added to the samples in quantities equivalent to $2 \mathrm{~mL} \mathrm{~h}^{-1}$ of sample under 1 -h reflux. The residue was dissolved again in $2 \mathrm{~mL}$ hexane containing $0.2 \mathrm{mg} \mathrm{mL}^{-1}$ 5 - $\alpha$ cholestane internal standard (IS) (Sigma, USA).

Cholesterol content was analyzed in a 14-A gas chromatograph (Shimadzu, Japan), equipped with a flame ionization detector and a fused silica capillary column (25 m-long, 0.25-mm internal diameter, and $0.20 \mu \mathrm{m}$ Ohio Valley-30). Injector, column, and detector temperatures were 260,280 , and $280{ }^{\circ} \mathrm{C}$, respectively. Ultra-pure gas fluxes (White Martins) of $1.5 \mathrm{~mL} \mathrm{~min}^{-1} \mathrm{H}_{2}$ as carrier gas, $30 \mathrm{~mL} \mathrm{~min}^{-1} \mathrm{~N}_{2}$ as make-up gas, $300 \mathrm{~mL} \mathrm{~min}^{-1}$ synthetic gas, and $30 \mathrm{~mL} \mathrm{~min}^{-1} \mathrm{~N}_{2}$ for flame were used.

The sample injection split mode was: 1:150. Peak integration was carried out with CG-300 computing integrator (CG Instruments, Brazil) and cholesterol was identified by comparison with standards from Sigma(USA). Sample cholesterol quantification was carried out after verification of method linearity. Standard cholesterol solutions (Sigma, USA) were prepared with concentrations $0.0 ; 0.4 ; 0.8 ; 1.6$, and $2.0 \mathrm{mg} \mathrm{mL}^{-1}$, all containing $0.20 \mathrm{mg} \mathrm{mL}^{-1}$ $5 \alpha$-cholestane (Sigma, USA), and analyzed. The ratio of the areas of cholesterol and 5- $\alpha$ cholestane was plotted against the cholesterol concentration for injected volumes of 0.0 ; $2.0 ; 3.0 ; 4.0$, and $5.0 \mu \mathrm{L}$. The curve obtained was used for cholesterol analysis in $\mathrm{mg} 100 \mathrm{~g}^{-1}$.

The fatty acids methyl esters were analyzed in a gas chromatograph (Varian, USA) equipped with a flame ionization detector and a fused silica capillary column CP-7420 (100 m, $0.25 \mathrm{~mm}$ and $0.39 \mu \mathrm{m}$ o.d., Varian, USA)
Select Fame. Column temperature was programmed at $165^{\circ} \mathrm{C}$ for $18 \mathrm{~min}, 180^{\circ} \mathrm{C}\left(30^{\circ} \mathrm{C} \mathrm{min}^{-1}\right)$ for $22 \mathrm{~min}$, and $240{ }^{\circ} \mathrm{C}\left(15^{\circ} \mathrm{C} \mathrm{min}^{-1}\right)$ for $30 \mathrm{~min}$, with 45 -psi pressure.

Injector and detector were kept at $220^{\circ} \mathrm{C}$ and $245^{\circ} \mathrm{C}$, respectively. The gas fluxes (White Martins) used were: $1.4 \mathrm{~mL} \mathrm{~min}^{-1}$ for the carrier gas $\left(\mathrm{H}_{2}\right) ; 30 \mathrm{~mL} \mathrm{~min}^{-1}$ for the make-up gas $\left(\mathrm{N}_{2}\right)$ and $30 \mathrm{~mL} \mathrm{~min}^{-1}$ and $300 \mathrm{~mL} \mathrm{~min}^{-1}$ for $\mathrm{H}_{2}$ and the synthetic flame gas, respectively. Sample injection split mode was $1 / 80$.

Fatty acids were identified by comparing the relative retention times of fatty acid methyl esters peaks of the samples with fatty acids methyl ester standards from Sigma (USA) by spiking samples with standard. The peak areas were determined by the Star software (Varian).

Data were expressed as percentages of the normalized area of fatty acids (Rowe et al., 1999; Milinsk et al., 2005).

Statistic analyses were interpreted by analysis of variance and the differences were evaluated by Tukey test at $5 \%$, analyzed by SAS software (Statistical Analysis System, version 8.1.) as the model:

$\mathrm{Y}_{\mathrm{ij}}=\mu+\mathrm{GG}_{\mathrm{i}}+\mathrm{e}_{\mathrm{ij}}$

in which: $Y_{i j}=$ ". " animal observation subjected to trial " ${ }_{i}$ "; $\mu=$ general constant; $\mathrm{GG}_{\mathrm{i}}=$ trial effect $_{\mathrm{i}} ;{ }_{\mathrm{i}}=1, \ldots, 4$; with $1=$ Caracu; 2 Canchin; $3=$ Aberdeen $\times$ Angus and $4=$ Charolais $\times$ Caracu; $\mathrm{e}_{\mathrm{ij}}=$ random error associated with each observation.

\section{Results and Discussion}

There were no differences $(\mathrm{P}>0.05)$ between genetic groups as to final weight, hot carcass weight, longissimus muscle area/100 kg carcass, color, marbling, muscle, fat and bone percentages (Table 2). Their means were: $519 \mathrm{~kg}, 275 \mathrm{~kg}, 25.6 \mathrm{~cm}^{2}, 3.43$ points, 4.94 points, $62.9 \%$, $21.6 \%$ and $15.5 \%$, respectively. Thus, these results show that genetic groups have a little influence on carcass characteristics of bulls finished in feedlot and fed with one energetic density high diet.

Hot carcass dressing was higher $(\mathrm{P}<0.05)$ than Canchin $(55.2 \%)$ genetic group in comparison with the three others genetic groups (Table 2). The genetic group Caracu presented the lowest $(50.4 \%)$ hot carcass dressing, whereas genetic groups Aberdeen Angus $\times$ Canchin and Charolais $\times$ Caracu presented similar $(\mathrm{P}>0.05)$ and intermediate hot carcass dressing (53.8 and 52.4\%, respectively). The genetic group that presented Zebu genes (Canchin) in their composition showed higher hot carcass dressing than genetic groups without Zebu genes. Prado et al. (2008a) suggest that heterosis is responsible for the higher value of hot carcass dressing. 
The carcass conformation was higher $(\mathrm{P}<0.05)$ for Canchin (15.5 points) genetic group in comparison with Caracu (12.1 points), Aberdeen Angus $\times$ Canchin (13.9 points) and Charolais $\times$ Caracu (13.3 points) genetic groups. However, there was no difference $(\mathrm{P}>0.05)$ between Caracu, Aberdeen Angus $\times$ Canchin and Charolais $\times$ Caracu genetic groups. According to the Müller score (1980), the score of approximately 14 points found to Aberdeen Angus $\times$ Canchin is considered very good 0 (VG0); the 15.1 points of Canchin is considered very good $+(\mathrm{VG}+)$; Caracu obtained 12.1 points and it is considered good $+\left(\mathrm{G}^{+}\right)$, and Charolais $\times$ Caracu obtained 13.3 points, which is considered very good $-(\mathrm{VG}-)$. The carcass conformation score changed from 1 (considered an inferior carcass) to 18 (considered a superior carcass). According to the Müller score, (Müller, 1980) the observed conformation can be considered adequate to meet the standards of the Brazilian markets.

Fat thickness was higher $(\mathrm{P}<0.05)$ for genetic groups Aberdeen Angus $\times$ Canchin (4.59 mm)in comparison with genetic groups Caracu (2.87 mm), Canchin $(3.56 \mathrm{~mm})$ and Charolais $\times$ Caracu $(3.81 \mathrm{~mm})$. The genetic group Caracu presented the lowest $(2.87 \mathrm{~mm})$ fat thickness, while genetic groups Canchin and Charolais $\times$ Caracu presented similar $(\mathrm{P}>0.05)$ and intermediate fat thickness $(3.56$ and $3.81 \mathrm{~mm}$, respectively). Canchin, Aberdeen Angus $\times$ Canchin and Charolais $\times$ Caracu genetic groups presented fat thickness values acceptable for the standard of Brazilian commercial refrigerating appliances (between 3 and $6 \mathrm{~mm}$ ).

There was no difference $(\mathrm{P}<0.05)$ between genetic groups for moisture, ashes, crude protein or total cholesterol (Table 3 ).

The moisture average $(73.3 \%)$ were similar to the values observed by Prado et al. (2008a) (73.4\%) and Rotta et al. (2009a) (73.9\%). Prado et al. (2008b) and Kazama et al. (2008) suggested that variation in moisture percentage occurs when there is variation in total lipids percentage. However, in this study, the total lipids percentage changes only from 1.29 to $1.47 \%$ among genetic groups.

Ash percentage has a low variation due to genetic groups. Ash percentage ranges from 1.03 to $1.15 \%$. Rotta et al. (2009a) suggest that variation in ash is low due to genetic groups.

In the same way, the variation to crude protein percentage was low. In this study, the lowest value was $22.5 \%$ (Canchin)

Table 2 - Carcass characteristics of Caracu (CAR), Canchin (CAN), Aberdeen Angus $\times$ Canchin $(\mathrm{AAC})$ and Charolais $\times$ Caracu $(\mathrm{CHC})$ genetic groups slaughtered at 22 months old

\begin{tabular}{|c|c|c|c|c|c|c|}
\hline \multirow[t]{2}{*}{ Carcass characteristic } & \multicolumn{4}{|c|}{$\mathrm{g}$} & \multirow[t]{2}{*}{ Means } & \multirow[t]{2}{*}{ SE } \\
\hline & CAR & CAN & $\mathrm{AAC}$ & $\mathrm{CHC}$ & & \\
\hline $\mathrm{n}$ & 8 & 8 & 8 & 8 & & \\
\hline Final live weight, $\mathrm{kg}$ & 496 & 527 & 516 & 536 & 519 & 11.9 \\
\hline Hot carcass weight, $\mathrm{kg}$ & 250 & 291 & 277 & 281 & 275 & 7.21 \\
\hline Hot carcass dressing, $\%$ & $50.4 \mathrm{c}$ & $55.2 \mathrm{a}$ & $53.8 \mathrm{~b}$ & $52.4 \mathrm{ab}$ & 53.0 & 0.52 \\
\hline Carcass conformation, points & $12.1 \mathrm{~b}$ & $15.1 \mathrm{a}$ & $13.9 \mathrm{~b}$ & $13.3 b$ & 13.6 & 0.37 \\
\hline Fat thickness, mm & $2.87 \mathrm{c}$ & $3.56 b$ & $4.59 \mathrm{a}$ & $3.81 \mathrm{~b}$ & 3.71 & 0.18 \\
\hline Longissimus muscle area, $\mathrm{cm}^{2}$ & $61.5 b$ & $76.6 \mathrm{a}$ & $69.8 \mathrm{ab}$ & $73.9 \mathrm{a}$ & 70.4 & 1.97 \\
\hline Longissimus muscle area $/ 100 \mathrm{~kg}$ carcass, $\mathrm{cm}^{2}$ & 24.8 & 26.2 & 25.2 & 26.4 & 25.6 & 0.75 \\
\hline Color, points & 3.50 & 3.25 & 4.00 & 3.00 & 3.43 & 0.16 \\
\hline Marbling, points & 5.00 & 4.00 & 6.25 & 4.50 & 4.94 & 0.12 \\
\hline Muscle, \% & 61.4 & 64.4 & 62.7 & 63.2 & 62.9 & 0.27 \\
\hline Fat, \% & 21.7 & 20.5 & 22.2 & 21.9 & 21.6 & 0.53 \\
\hline Bone, \% & 16.7 & 15.1 & 15.2 & 14.9 & 15.5 & 0.53 \\
\hline
\end{tabular}

SE - stardard error.

Means in the same row with different letters are different $(\mathrm{P}<0.05)$ by Tukey test

Table 3 - Chemical composition of the longissimus muscle of Caracu (CAR), Canchin (CAN), Aberdeen Angus $\times$ Canchin (AAC) and Charolais $\times$ Caracu (CHC) slaughtered at 22 months old

\begin{tabular}{|c|c|c|c|c|c|c|}
\hline \multirow[t]{2}{*}{ Chemical composition } & \multicolumn{4}{|c|}{ Genetic groups } & \multirow[t]{2}{*}{ Means } & \multirow[t]{2}{*}{ SE } \\
\hline & CAR & $\mathrm{CAN}$ & $\mathrm{AAC}$ & $\mathrm{CHC}$ & & \\
\hline Number & 8 & 8 & 8 & 8 & & \\
\hline Moisture, \% & 72.9 & 73.5 & 72.8 & 73.3 & 73.2 & 0.19 \\
\hline Ash, \% & 1.07 & 1.15 & 1.10 & 1.03 & 1.09 & 0.02 \\
\hline Crude protein, \% & 22.6 & 22.5 & 22.6 & 22.9 & 22.6 & 0.17 \\
\hline Total lipids, \% & $1.41 \mathrm{a}$ & $1.29 b$ & $1.47 \mathrm{a}$ & $1.37 \mathrm{~b}$ & 1.38 & 0.02 \\
\hline Total cholesterol $^{1}$ & 36.1 & 36.8 & 36.2 & 36.4 & 36.4 & 0.10 \\
\hline
\end{tabular}

SE - stardard error.

${ }^{1} \mathrm{mg} / 100 \mathrm{~g}$ of muscle.

Means in the same row with different letters are different $(\mathrm{P}<0.05)$ by Tukey test. 
and the highest value was $22.9 \%$ (Charolais $\times$ Caracu). Prado et al. (2008a,b,c) and Rotta et al. (2009a) suggest that crude protein percentage in the longissimus muscle is not altered by genetic groups.

The total lipids percentage was lower $(\mathrm{P}<0.05)$ for genetic groups Canchin $(1.29 \%)$ and Charolais $\times$ Caracu $(1.37 \%)$. However, there was no difference between Caracu $(1.41 \%)$ and Aberdeen Angus $\times$ Canchin (1.47\%). Increases in intramuscular fat are observed in bulls with higher degree of finishing, respecting the biological chronogram of fat deposition, which starts as visceral fat, followed by extra muscular fat and subsequent intramuscular fat (Prado et al., 2009a). The lower lipids percentage in Canchin and Charolais $\times$ Caracu bulls is due the zebu genes that reduce fat deposition.

There was no difference $(\mathrm{P}>0.05)$ as for total cholesterol percentage between genetic groups, with mean value of $36.4 \mathrm{mg} / 100 \mathrm{~g}$ of muscle. The total cholesterol percentage changes between 34.1 and $52.9 \mathrm{mg} / 100 \mathrm{~g}$ in the longissimus muscle (Prado et al., 2008d; Prado et al., 2009a; 2009b; 2009c). Prado et al. (2009b) suggested that the presence of Zebu genes in the makeup of genetic groups appears to result in higher total cholesterol levels in the longissimus muscle, perhaps as a result of an increase in muscle membranes. Nevertheless, the total cholesterol level observed is near that regarded as harmful to human health, which is set to $\leq 50 \mathrm{mg} / 100 \mathrm{~g}$ of muscle (Prado et al., 2008c; Saucier, 1999).

Most of the fatty acids analyzed in the longissimus muscle of bulls from different genetic groups were: 16:0 (29.9\%), 18:0 (15.9\%) and 18:1 n-9 (36.0\%) and represent $81.8 \%$ of the total fatty acid profile. There was no difference $(\mathrm{P}>0.05)$ to the most of fatty acids in the longissimus muscle (Table 4).

The levels of $\mathrm{C} 14: 0$ (myristic acid) were higher $(\mathrm{P}<0.05)$ in Caracu (3.19\%) bulls. Canchin (2.47\%), Aberdeen Angus $\times$ Canchin $(2.61 \%)$ and Charolais $\times$ Caracu $(2.30 \%)$ groups featured lower levels of this acid. The mean percentage of C14:0 (myristic acid) was $2.30 \%$. Similar values $(2.34 \%)$ were observed by Aricetti et al. (2008) who used crossbred bulls, although finished in pasture system. The percentage of $\mathrm{C} 16: 0$ (palmitic acid) was similar ( $\mathrm{P}>0.05)$ in bulls of the four genetic groups. The mean percentage was $29.9 \%$. Kazama et al. (2008) and Rotta et al. (2009b) showed that C16:0 percentage can be changed from $25 \%$ to $30 \%$ in the longissimus muscle of crossbred bulls finished in feedlot. Fatty acids C14:0 and C16:0 are considered hypercholesterolemic; they are responsible for the increase in quantity of lipoproteins of low density (LDL) that are responsible for heart disease. Some foods with low amounts

Table 4 - Fatty acid profile longissimus muscle of Caracu (CAR), Canchin (CAN), Aberdeen Angus $\times$ Canchin (AAC) and Charolais $\times$ Caracu (CHC) genetic groups slaughtered at 22 months of age

\begin{tabular}{|c|c|c|c|c|c|c|}
\hline \multirow[t]{2}{*}{ Fatty acid profile } & \multicolumn{4}{|c|}{ Genetic groups } & \multirow[t]{2}{*}{ Means } & \multirow[t]{2}{*}{ SE } \\
\hline & CAR & $\mathrm{CAN}$ & AAC & $\mathrm{CHC}$ & & \\
\hline Number & 8 & 8 & 8 & 8 & & \\
\hline $14: 1 \quad n-7$ & 0.41 & 0.33 & 0.37 & 0.31 & 0.35 & 0.02 \\
\hline $15: 0$ & 0.23 & 0.27 & 0.27 & 0.24 & 0.25 & 0.01 \\
\hline $15: 1 \quad n-9$ & $0.17 \mathrm{a}$ & $0.18 \mathrm{a}$ & $0.18 \mathrm{a}$ & $0.12 \mathrm{~b}$ & 0.16 & 0.01 \\
\hline $16: 1 \quad n-7$ & 3.56 & 2.81 & 2.97 & 2.87 & 3.05 & 0.11 \\
\hline $16: 1 \quad n-5$ & 0.36 & 0.41 & 0.43 & 0.37 & 0.39 & 0.01 \\
\hline $17: 0$ & 0.59 & 0.70 & 0.70 & 0.63 & 0.65 & 0.02 \\
\hline $17: 1 \quad n-9$ & 0.44 & 0.45 & 0.43 & 0.46 & 0.44 & 0.01 \\
\hline $18: 0$ & 15.4 & 15.2 & 16.6 & 16.5 & 15.9 & 0.24 \\
\hline $18: 1 \quad t-11$ & 0.51 & 0.55 & 0.53 & 0.54 & 0.53 & 0.02 \\
\hline CLA $c-9, t-11$ & 0.22 & 0.26 & 0.22 & 0.23 & 0.23 & 0.01 \\
\hline $22: 0$ & $0.04 \mathrm{a}$ & $0.02 b$ & $0.03 \mathrm{ab}$ & $0.03 \mathrm{ab}$ & 0.03 & 0.01 \\
\hline $20: 4 n-6$ & $1.46 \mathrm{~b}$ & $2.15 \mathrm{a}$ & $1.52 \mathrm{ab}$ & $1.59 \mathrm{ab}$ & 1.68 & 0.09 \\
\hline $20: 5 n-3$ & 0.14 & 0.20 & 0.16 & 0.18 & 0.17 & 0.01 \\
\hline $22: 5 n-3$ & $0.40 \mathrm{~b}$ & $0.65 \mathrm{a}$ & $0.39 b$ & $0.52 \mathrm{ab}$ & 0.49 & 0.01 \\
\hline $22: 6 n-3$ & 0.10 & 0.10 & 0.09 & 0.13 & 0.11 & 0.03 \\
\hline
\end{tabular}


of these fatty acids are required. However, in the longissimus muscle, the percentage of $\mathrm{C} 14: 0$ and $\mathrm{C} 16: 0$ is considered high (35\% of the total acids) (Prado et al., 2008b; Prado et al., 2009b; Rotta et al., 2009b).

The fatty acid C18:0 (stearic acid) percentage was similar $(\mathrm{P}>0.05)$ for the different genetic groups. The mean percentage was $15.9 \%$. Prado et al. (2009a; b) and Rotta et al. (2009b) showed that C18:0 percentage can be changed from $19 \%$ to $22 \%$ in the longissimus muscle of crossbred bulls finished in feedlot.

The fatty acid 18:1 n-9 (oleic acid) was similar ( $\mathrm{P}>0.05)$ among the genetic groups. The mean percentage was $36.4 \%$. Prado et al. (2008a; Prado et al., 2009a) and Prado et al., (2009a); Rotta et al. (2009b) showed that the C18:1 n-9 percentage can change from $33 \%$ to $38 \%$ in the longissimus muscle of crossbred bulls finished in feedlot.

Fatty acid 18:3n-3 was higher $(\mathrm{P}<0.05)$ for genetic groups Canchin $(0.43 \%)$ and Charolais $\times$ Caracu $(0.40 \%)$. Lower results of 18:3 n-3 were observed by Rotta et al. (2009a) for Caracu (0.18\%). Prado et al. (2008a) observed inferior results for genetic group Aberdeen Angus $x$ Canchin (0.12\%). However, Prado et al. (2008c) observed values superior to $18: 3 n-3$ for genetic group Charolais $\times$ Caracu $(0.73 \%)$.

Fatty acid 20:4 n-6 was higher $(\mathrm{P}<0.05)$ for genetic group Canchin (2.15\%). There was no difference $(\mathrm{P}>0.05)$ for the Caracu (1.46\%), Aberdeen Angus $\times$ Canchin (1.52\%) or Charolais $\times$ Caracu $(1.59 \%)$ genetic groups. Fatty acid $22: 5 n-3$ was higher $(\mathrm{P}<0.05)$ for Canchin $(0.65 \%)$ and Charolais $\times$ Caracu $(0.52 \%)$ genetic groups, although there was no difference $(\mathrm{P}>0.05)$ for the Caracu or Aberdeen Angus $\times$ Canchin genetic groups.

Saturated fatty acids represent approximately $50 \%$ of the total composition in analyzed fatty acids in the longissimus muscle of four genetic groups slaughtered at 22 months of age (Table 5). There was no difference $(\mathrm{P}<0.05)$ for the sum of saturated fatty acids and monounsaturated fatty acids. Likewise, Aricetti et al. (2008) and Prado et al. (Prado et al., 2008a,b,c,d) observed similar percentages of saturated fatty acids and monounsaturated fatty acids in bulls from different crossbreeding systems finished under similar diets. Thus, saturated and monounsaturated fatty acids percentages vary little as function of genetic groups.

The sum of polyunsaturated fatty acids was higher $(\mathrm{P}>0.05)$ for Canchin (11.0\%), and lower for genetic groups Caracu (7.47\%), Aberdeen Angus $\times$ Canchin (6.89\%) and Charolais $\times$ Caracu (8.44\%). Polyunsaturated fatty acids present a variation from 4 to $11 \%$ (Rotta et al., 2009a). Genetic groups that have Zebu genes in their composition show high percentage of polyunsaturated fatty acids.

The sum of $n-6$ was higher $(\mathrm{P}>0.05)$ for Canchin $(9.3 \%)$ in comparison with genetic groups Caracu (6.34\%), Aberdeen Angus $\times$ Canchin $(5.75 \%)$ and Charolais $\times$ Caracu (6.98\%). However, there was no difference $(\mathrm{P}>0.05)$ for Caracu, Aberdeen Angus $\times$ Canchin and Charolais $\times$ Caracu genetic groups. The $n-6$ percentage ranges from 3.5 to 9.3 (Rotta et al., 2009a).The genetic groups that have the zebu genes in their composition show high percentages of this category of fatty acids (Prado et al., 2008b; c). This can be because of genetic groups that have more polyunsaturated fatty acids in their fatty acid profile.

The sum of $n-3$ was higher $(\mathrm{P}>0.05)$ for Canchin $(1.38 \%)$ and Charolais $\times$ Caracu $(1.23 \%)$ in relation to Caracu $(0.90 \%)$ and Aberdeen Angus $\times$ Canchin (0.92\%) genetic groups. However, there was no difference $(\mathrm{P}>0.05)$ between Canchin and Charolais $\times$ Caracu genetic groups and Caracu and Aberdeen Angus $\times$ Canchin genetic groups. Different values were verified by Kazama et al. (2008) and Prado et al. (2008a), who observed inferior values of $n-3$ for genetic group Angus $\times$ Canchin of $0.48 \%$.

The polyunsaturated:saturated fatty acids ratio was higher $(\mathrm{P}<0.05)$ for Canchin $(0.23)$ in comparison with the Caracu (0.15), Aberdeen Angus $\times$ Canchin (0.14) and Charolais $\times$ Caracu $(0.17)$ genetic groups $(0.17 \%)$. However,

Table 5 - Sum and ratios of fatty acids of longissimus muscle of genetic groups Caracu (CAR), Canchin (CAN), Aberdeen Angus $\times$ Canchin (AAC) and Charolais $\times$ Caracu $(\mathrm{CHC})$ slaughtered at 22 months old

\begin{tabular}{|c|c|c|c|c|c|c|}
\hline \multirow[t]{2}{*}{ Fatty acids } & \multicolumn{4}{|c|}{ Genetic groups } & \multirow[t]{2}{*}{ Means } & \multirow[t]{2}{*}{$\mathrm{SE}$} \\
\hline & CAR & $\mathrm{CAN}$ & AAC & $\mathrm{CHC}$ & & \\
\hline Number & 8 & 8 & 8 & 8 & & \\
\hline SFA & 49.6 & 48.5 & 50.3 & 49.1 & 49.4 & 0.34 \\
\hline MUFA & 42.9 & 40.5 & 42.9 & 42.4 & 42.2 & 0.36 \\
\hline PUFA & $7.47 b$ & $11.0 \mathrm{a}$ & $6.89 \mathrm{~b}$ & $8.44 b$ & 8.44 & 0.38 \\
\hline$n-6$ & $6.35 \mathrm{~b}$ & $9.30 \mathrm{a}$ & $5.75 \mathrm{~b}$ & $6.98 \mathrm{~b}$ & 7.10 & 0.35 \\
\hline$n-3$ & $0.90 \mathrm{~b}$ & $1.38 \mathrm{a}$ & $0.92 b$ & $1.23 \mathrm{a}$ & 1.10 & 0.05 \\
\hline PUFA/SFA & $0.15 b$ & $0.23 \mathrm{a}$ & $0.14 b$ & $0.17 b$ & 0.17 & 0.01 \\
\hline$n-6 / n-3$ & 7.06 & 6.74 & 6.28 & 5.67 & 6.44 & 0.33 \\
\hline
\end{tabular}

SE - stardard error; SFA - saturated fatty acids; MUFA - monounsaturated fatty acids; PUFA - polyunsaturated fatty acids. Means in the same row with different letters are different $(\mathrm{P}<0.05)$ by Tukey test. 
there was no difference $(\mathrm{P}>0.05)$ between genetic groups Caracu, Aberdeen Angus $\times$ Canchin and Charolais $\times$ Caracu. polyunsaturated fatty acids/saturated fatty acids ratio ranges between 0.08 and 0.22 (Rotta et al., 2009a). This ratio plays important role in reducing the risk of coronary heart disease (Hu, 2001). The recommended ratio by the England Department of Health (1994) is 0.45 ; therefore, the values found in this experiment are far from recommended.

There was no difference $(\mathrm{P}>0.05)$ as to $n-6 / n-3$ ratio, with an average of 6.44. However, this value is near the recommended by the England Department of Health (1994), which is $4: 1$. Prado et al. (2003) evaluated the fatty acid profile in Bos taurus indicus and Bos taurus indicus $\times$ Bos taurus taurus crossbred finished on pasture and observed that animals from forage diets show lower values for $n-6 / n-3$ ratio (1.27) in relation to animals finished in feedlot, which present higher $n-6 / n-3$ ratio (8.30) (Prado et al., 2008b).

\section{Conclusions}

The higher fat level provides more flavor to beef, increasing its palatability. However, in terms of consumer health, the increase in fat content could be harmful. On the other hand, genetic groups have a certain influence on the chemical composition and fatty acid profile of the longissimus muscle of animal finished in feedlot. The difference is related to the origin of the various genetic groups. Cattle with zebu genes have the highest levels of unsaturated fatty acids, due to characteristics in fiber composition and a higher percentage of muscle collagen. However, genetic manipulation has shown only little variation in beef composition.

\section{Acknowledgments}

This study was supported by the Fundação Araucária and the Conselho Nacional de Desenvolvimento Científico e Tecnológico (CNPq).

\section{References}

ASSOCIATION OF OFFICIAL ANALYTICAL CHEMISTS - AOAC, Official methods of analysis. 16.ed. Arlington: AOAC International, 1998. $1025 \mathrm{p}$.

ARICETTI, J.A.; ROTTA, P.P.; PRADO, R.M. et al. Carcass characteristics, chemical composition and fatty acid profile of Longissimus muscle of bulls and steers finished in a pasture system. Asian-Australasian Journal of Animal Science, v.21, p.1441-1448, 2008 .

BLIGH, E.G.; DYER, W.J. A rapid method of total lipid extraction and purification. Canadian Journal of Biochemical and Physiology, v.3, p.911-917, 1959.
COUNCIL FOR INTERNATIONAL ORGANIZATIONS OF MEDICAL SERVICES - CIOMS/OMS. WHO Distribuition and sales service, 1985, 1211 Geneva 27, Switzerland, International Guiding Principles for Biomedical Research Involving Animals.

DUCATTI, T.; PRADO, I.N.; ROTTA, P.P. et al. Chemical composition and fatty acid profile in crossbred (Bos taurus vs. Bos indicus) young bulls finished in a feedlot. Asian-Australasian Journal of Animal Science, v.22, p.433-439, 2009.

HANKINS, O.G.; HOWE, P.E. Estimation of the composition of beef carcasses and cuts. Washington: United States Department of Agriculture, 1946. 20p. (Technical Bulletin, 926).

HMSO (England). Department of Health. Nutritional aspects of cardiovascular disease. London: HMSO, 1994. p.37-46. (Report on Health and Social Subjects, 46).

HU, F.B. The balance between $w-6$ and $w-3$ fatty acids and the risk of coronary heart disease. Nutrition, v.17, p.741-742, 2001

INTERNATIONAL ORGANIZATION FOR STANDARDIZATION - ISO. Animal and vegetable fats and oils - Preparation of methyl esters of fatty acids. Geneva: 1978. Method 5509, p.1-6.

KAZAMA, R.; ZEOULA, L.M.; PRADO, I.N. et al. Características quantitativas e qualitativas da carcaça de novilhas alimentadas com diferentes fontes energéticas em dietas à base de cascas de algodão e de soja. Revista Brasileira de Zootecnia, v.37, p.350-357, 2008.

MILINSK, M.C.; PADRE, R.G.; HAYASHI, C. et al. Effects of feed protein and lipid contents on fatty acid profile of snail (Helix aspersa maxima) meat. Journal Food Composition Analysis, v.19, p.212-216, 2005

MOREIRA, F.B.; SOUZA, N.E.; MATSUSHITA, M. et al. Evaluation of carcass characteristics and meat chemical composition of Bos indicus $\times$ Bos taurus crossbred steers finished in pasture systems. Brazilian Archives of Biology and Technology, v.46, p.609-616, 2003

MÜLLER, L.; MAXON, W.E; PALMER, A.Z. Memoria de la Associación Latinoamericana de Producción Animal, 1973, Guadalajara. Anais... Guadalajara, 1973. p.1-3

MÜLLER, L. Normas para avaliação de carcaças e concurso de carcaças de novilhos. Santa Maria: Imprensa Universitária - UFSM, 1980. 31p.

NATIONAL RESEARCH COUNCIL - NRC. Nutrient requirements of beef cattle. 6.ed. Washington, D.C.: National Academy Press, 1996. 242p.

PRADO, I.N.; MOREIRA, F.B., MATSUHITA, M. Longissimus dorsi fatty acids composition of Bos indicus and Bos indicus'Bos taurus crossbred steers finished on pasture. Brazilian Archives of Biology Technical, v.46, p.606-608, 2003.

PRADO, I.N.; ARICETTI, J.A.; ROTTA, P.P. et al. Carcass characteristics, chemical composition and fatty acid profile of the Longissimus muscle of bulls (Bos taurus indicus vs. Bos taurus taurus) finished in pasture systems. Asian-Australasian Journal of Animal Science, v.21, p.1449-1457, 2008a.

PRADO, I.N.; ITO, R.H.; PRADO, J.M. et al. The influence of dietary soyabean and linseed on the chemical composition and fatty acid profile of the Longissimus muscle of feedlot-finished bulls. Journal of Animal and Feed Science, v.17, p.307-317, 2008 b.

PRADO, I.N.; PRADO, R.M.; ROTTA, P.P. et al. Carcass characteristics and chemical composition of the Longissimus muscle of crossbred bulls (Bos taurus indicus vs. Bos taurus taurus) finished in feedlot. Journal of Animal and Feed Sciences, v.17, p.295-306, 2008c

PRADO, I.N.; ROTTA, P.P.; PRADO, R.M. et al. Carcass characteristics and chemical composition of the Longissimus muscle of Puruna and 1/2 Puruna vs. 1/2 Canchin bulls meat quality of bulls. Asian-Australasian Journal of Animal Science, v.21, p.1296-1302, 2008d.

PRADO, I.N.; OLIVEIRA, A.N.; ROTTA, P.P. Chemical and fatty acid composition of Longissimus muscle of crossbred bulls 
finished in feedlot. Asian-Australasian Journal of Animal Science, v.22, p.1054-1059, 2009a.

PRADO, J.M.; PRADO, I.N.; VISENTAINER, J.V. et al. The effect of breed on the chemical composition and fatty acid profile of the Longissimus dorsi muscle of Brazilian beef cattle. Journal of Animal and Feed Sciences, v.18, p.231-240, 2009b.

PRADO, R.M.; PRADO, I.N.; MARQUES, J.A. et al. Meat quality of the Longissimus muscle of bulls and steers (1/2 Nellore vs. 1/2 Simmental) finished in feedlot. Journal of Animal and Feed Sciences, v.18, p.221-230, 2009c.

ROTTA, P.P.; PRADO, I.N.; PRADO, R.M. et al. Carcass characteristics and chemical composition of the Longissimus muscle of Nellore, Caracu and Holstein-friesian bulls finished in a feedlot. Asian-Australasian Journal of Animal Science, v.22, p.598-604, 2009a.
ROTTA, P.P.; PRADO, R.M.; PRADO, I.N. et al. The effects of genetic groups, nutrition, finishing systems and gender of Brazilian cattle on carcass characteristics and beef composition and appearance: a review. Asian-Australasian Journal of Animal Science, v.22, p.1718-1734, 2009b.

ROWE, A.; MACEDO, F.A.F.; VISENTAINER, J.V. et al. Muscle composition and fatty acid profile in lambs fattened in drylot or pasture. Meat Science, v.51, p.283 288, 1999.

SAUCIER, L. Meat safety: challenges for the future. Nutrition Abstratcs Review (Series A), v.69, p.705-708, 1999.

WEBB, E.C. Manipulating beef quality through feeding. South African Journal of Food Science Nutrition, v.7, p.1-24, 2006.

WOOD, J.D.; RICHARDSON, R.I.; NUTE, G.R. et al. Effects of fatty acids on meat quality: a review. Meat Science, v.66, p.21-32, 2003. 